\title{
On Sexualisation and Eroticisation: emancipation of love and lust
}

\author{
Cas Wouters' \\ 'Utrecht University (UU), Utrecht/TC - Netherlands
}

\begin{abstract}
On Sexualisation and Eroticisation: emancipation of love and lust ${ }^{1}$. This paper pursues understanding recent changes in the romantic and sexual relations of young people. Its perspective focuses on the emancipation of women and young people since the 1880s, a moment when social codes dominating the relations between women and men, parents and their children, changed towards greater leniency. Both had to learn how to become sexual subjects as well as sexual objects and to develop a gratifying balance between the two, in trial-and-error processes involving attempts at connecting sexual and relational intimacy in subsequent spurts of sexualisation and eroticisation. The paper sketches significant moments in these processes and raises the question of where we are now.

Keywords: Sexualisation. Erotisation. Balance of Power. Informalisation. Emotion Regulation.
\end{abstract}

RESUMO - Sexualização e Erotização: emancipação e integração do amor e do sexo. $\mathrm{O}$ artigo trata das recentes mudanças nas relações românticas e sexuais entre os jovens. A perspectiva centra-se na emancipação de mulheres e jovens desde a década de 1880, momento em que os códigos sociais que dominam as relações entre mulheres e homens, pais e filhos, ganharam maior leniência. Umas e outros tiveram de aprender como se tornar sujeitos sexuais e também objetos sexuais, desenvolvendo um equilíbrio gratificante entre os dois, em processos de tentativa e erro que envolveram esforços de conectar intimidade sexual e relacional em surtos subsequentes de sexualização e erotização. $\mathrm{O}$ artigo aponta momentos significativos nesses processos e levanta a questão de onde estamos agora.

Palavras-chave: Sexualização. Erotização. Balança de Poder. Informalização. Regulação das Emoções.

Educação \& Realidade, Porto Alegre, v. 42, n. 4, p. 1217-1234, Oct./Dec. 2017.1217 http://dx.doi.org/10.1590/2175-623664282 
On Sexualisation and Eroticisation

\section{Introduction: formalisation and informalisation}

What we people know about life and how to live it, that is, our knowledge and our codes of behaviour and feeling, is taught and appropriated in love and learn relationships and in love-and-learn processes (Elias, 2009a). These concepts, coined by Norbert Elias, implicitly recognise that for understanding the history of humanity at large as well as the history of any particular society and every individual human being, the history of love is as important as the history of learning. The two are closely connected, ever since the advent of Homo sapiens, when social codes came to dominate genetic codes as steering mechanisms for survival. Since then, the human offspring needs to be adjusted to the prevalent social codes and initiated in the reservoir of social knowledge. Both individual learning and transmitting collective knowledge over subsequent generations depend upon the cohesive strength and warmth of their bonds, particularly those involving children. The fundamental importance of human love-and-learn relations and processes is mirrored in their fears and anxieties: "[...] genetically, the whole family tree of fears and anxieties seems to have a twofold root: the fear of physical extinction and the fear of loss of love. Threats to one's life and one's love in a very elementary form seem to be the original danger situations" (Elias, 2009b, p. 140). In turn, the structure of people's fears and anxieties as well as the qualities of their bonds of love depend upon the levels of social organisation, pacification and civilisation in and between their societies: "[...] they are always determined, finally, by the history and the actual structure of his or her relations to other people, by the structure of society; and they change with it" (Elias, 2012, p. 485).

In expanding networks of human interdependence, from the fire regime - the social organisation of controlling fire - to the agrarian regime and the industrial regime, the levels of differentiation, integration and complexity have risen together with rising social controls of people over each other and themselves (Goudsblom, 1992). As human groups expanded, differentiated, and became increasingly complex, the same happened with their codes of behaviour and their collective stock knowledge: both also expanded and differentiated, becoming more detailed and complex, thus keeping people from transgressing the prevailing steering codes and demanding higher levels of self-regulation. On the whole, this was a long-term process of formalisation of social codes that was documented in Elias' book On the Civilising Process Elias (2012). It remained dominant up to the second half of the nineteenth century.

Around the 1880s, the unplanned social processes of differentiation, integration and growing complexity, together with their inherent social constraints toward self-constraint reached a critical level that allowed for - and soon also demanded - a partial breakthrough in the process of the formalisation of steering codes. This happened when the old rigid social controls together with their fixed rules of behaviour and their demand for unthinking obedience to social superiors lost their function to maintain social organisations and even tended to become

1218 Educação \& Realidade, Porto Alegre, v. 42, n. 4, p. 1217-1234, Oct./Dec. 2017. 
counter-productive. Then, a long-term process of informalisation became dominant (Wouters, 2007; 2015). A rapidly increasing variety of relations and situations in complex networks of interdependency had come to demand larger degrees of fine-tuning than at earlier times. This fine-tuning implied manoeuvring in increasingly flexible and sensitive ways according to more flexible guidelines, thus opening up a wider range of acceptable behavioural options.

The choosing among options, however, did not make behaviour easier, because making the right choices among a complex multitude of options came to depend on social skills that could no longer be learned on the basis of simply being obedient to authorities and fixed rules. It demanded the capacity to attune oneself to (changes in) the specific parameters of each particular relation and situation. These demands coincided with rising empathy together with openness, ease and reflexive caution. People were increasingly drawn into the social competition of learning the necessary skills and preform them with ease, and this competition intensified in the course of following decades and spread from circles of calculating politicians and commercial entrepreneurs to the much wider circles of calculating citizens. In this competition, the personality capital of a habitus that allows for more subtle, sensitive and flexible behaviour turned into a national habitus, and more or less simultaneously, into the international habitus of the rich West.

\section{Informalisation in Relations Between Parents and Children}

As a whole, these developments demanded a prolonged as well as a more intimate process of teaching and learning social steering codes, thus prolonging both parenthood and childhood. Parents and children not only became more strongly interdependent, their relations also became more intimate and more intense (see Röling, 2006). Both transformations were captured in the expression century of the child (Key, 1905 [1900]). Particularly in this century, the emancipation of children and teenagers in relation to parents and their representatives - and of women in relation to men - clearly implied rising levels of equality as well as of intimacy.

Since about the 1880s, traditional emphasis in child rearing shifted from emphasising subservience to institutional and adult authority, sanctioned by corporal and other punishments, to an emphasis on qualities linked to the self-regulation of children, sanctioned by reasoning and differentiations in warmth and permissiveness. Emotional investment in love-and-learn relations accelerated particularly since the 1950s and 1960s, when this trend was backed up by rising levels of material security and physical safety. Parents developed more intimate relations with their children and in these relations, children experienced a type of discipline or social control that was less directed at obedience than at self-control and self-steering, that is, at learning to think and decide for themselves (cf. Alwin, 1988). Simultaneously, having and raising children became increasingly important for providing an unthinking

Educação \& Realidade, Porto Alegre, v. 42, n. 4, p. 1217-1234, Oct./Dec. 2017.1219 
On Sexualisation and Eroticisation

sense of belonging and a source of motivation in life, whereas religion and political ideology, even social class, gender, and nationality lost much of that capacity. For increasing numbers of people, the love-andlearn relations with their children became a major provider of meaning in their life and their strongest motivating power. In raising children, a warmer and more intimate, flexible and cautious parental control on the self-control of children spread and became known as love-oriented discipline (Bronfenbrenner, 1958).

\section{Gender and Sex: the lust-balance}

The general trend towards rising empathy, openness and reflexive caution in relations particularly pertains to relations involving sexuality. The emancipation of women and young people went hand in hand with an emancipation of their sexuality, and at the same time, parents - of different social classes to varying degrees - have taken more of the interests and feelings of their children into account and also more of the sexuality of their teenagers. However, it was only since the Sexual Revolution that women, including young women themselves have actively taken part in public discussions about their carnal desires and how to achieve a more satisfactory lust-balance - the balance between longings for sexual gratification and for enduring relational intimacy. From then on, increasingly large groups of people have been experimenting in try-out relations between the extremes of desexualized love (sexual longing subordinated to the continuation of a relationship) and depersonalized sexual contact, and the extremes of becoming a sexual object and a sexual subject. This try-out process provoked many new and more varied answers to what might be called the lust-balance question: when and within what kinds of relationship(s) are (what kinds of) eroticism and sexuality allowed and desired? From the 1960s onwards, topics and practices such as premarital sex, sexual variations, unmarried cohabitation, adultery, fornication, extramarital affairs, jealousy, homosexuality, pornography, teenage sex, abortion, exchange of partners, paedophilia, incest and so on, all part of a wider process of sexualisation, implied repeated up-rooting confrontations with the traditional lustbalance. People were confronted with the lust-balance question more frequently and intensely than ever before.

This question is first raised in puberty or adolescence when bodily and erotic impulses and emotions that were banned from interaction from early childhood onwards (except in cases of incest and paedophilia) are again explored and experimented with. The original need for bodily contact of small children and their subsequent frank and spontaneous explorations stay without mirroring (Fonagy, 2008) and seem to be restricted and stopped when adults begin to experience them as sexual. Sexuality and corporality are thus separated from other forms of contact and compartmentalised. In puberty and adolescence, when the longings and demands for intimacy and confidentiality of teenagers are already quite developed, the taboo on touching and bodily contact has to be gradually dismantled. More or less overcome by their new long- 
ing for sexual pleasure and gratification, young people have to integrate this longing into both their personality and their relations. They have to learn how to become a sexual subject and a sexual object and to find a balance between the two. For most, this is a process of trial and error. In the process of sexualisation and eroticisation, especially since the Sexual Revolution, women collectively came into a similar position as young people when becoming sexually mature: both entered the trial and error process of becoming more of a sexual subject.

\section{Trial and Error as a Collective Processes: sexualization and eroticization}

In the twentieth century, especially since the 1960s, this process of trial and error has been going on collectively. Allowing for differences in nationality and social class, the subsequent moments of collective learning processes determined to a large extent the range of available options that individuals living in each moment saw themselves confronted with. Since the 1880s, over decades in which women emancipated, men accommodated, and young people continued to escape from under their parents' wings, this range widened considerably. Until the 1960s, however, a highly uneven balance of power between men and women, together with a highly compartmentalised sexuality kept a woman's carnal desires and experiences unmentionable. It made for sexual relations that were not necessarily confidential, even between husband and wife. Sexual intimacy did not demand much relational or personal intimacy. This is typical for a lust balance in which the longing for sex and the longing for enduring relational intimacy are not strongly integrated, can be even highly segregated.

The view on widening options and a collective process of trial and error seems in conflict with the fact that in most Western countries, the old rule of sexual abstinence before marriage was formally maintained up to the 1960s. However, this impression of conflict is wrong because increasingly people just paid lip-service, they did not live up to this rule and practiced the policy of don't ask, don't tell. Dutch research - my major source of data - shows that young people of the generation born at the beginning of the twentieth century postponed their first coitus on average until ten years after becoming sexually mature. The generation of about 1935 waited seven years, an average decline of 10 months per 10 years. This downward trend continued, for the generation of 1970 waited 5 years, which was a decline of 7 months per 10 years. Apparently, this decline was at a slower pace than that of the generations before World War II (Vliet, 1990). And although the pill did of course allow for more and more varied sexuality and for greater emotional tranquillity in seeking sexual pleasure, these findings nevertheless seem to allow the conclusion that the Sexual Revolution was not as revolutionary in terms of such crucial sexual behaviour as first carnal love as it was in terms of opening the public debate on sexuality and of stopping the hypocrisy of formally upholding the ban on premarital sexuality.

Educação \& Realidade, Porto Alegre, v. 42, n. 4, p. 1217-1234, Oct./Dec. 2017.1221 
On Sexualisation and Eroticisation

However, as the balance of power between women and men as well as between parents and children became less uneven, possibilities for more frank and warm intimate relations increased... as did the necessity to develop such relations. For men, the change was mainly towards an eroticization or sensualisation of sex. Male sexual pleasure came to depend more strongly upon the sensual or erotic bond with the sex partner, that is, upon relational intimacy. They also came to experience women not mainly as sexual objects but as much as sexual subjects. For women, the change was towards a sexualization of love and becoming a sexual subject as much as a sexual object. Together, these changes made for one integrated process of sexualisation and eroticisation that permeated across the board of social life, private as well as public. As the part-process of sexualization draws much more attention, also because it repeatedly provoked moral indignation, the significance of the part-process of eroticisation is often only partly acknowledged.

\section{Trial and Error before the 1960s: two social class trajectories}

Until the 1960s, the trial and error process towards easier and comradelier relations between women and men has many trajectories but at least two that are differentiated by social class. One trajectory involves good society [gute Gesellschaft] and groups of families largely directing themselves to its model, In the 1880s, young people from these social classes had limited opportunities to select a marriage partner that stage been set by parents strictly controlling courtship activities. An example is dancing, which was held in high esteem as a courting arena. Only at a private ball or diner-dance could a young man dance with a girl of this social class. But first he had to ask her parents for permission, and when he was listed in her dancing programme he might opt for a second dance with the same girl, but opting for a third dance would create expectations and obligations, directly connected to getting engaged and then married. This scene changed as young women went out to work in such places like offices, libraries, hospitals, and schools, and aimed at financial independence. In addition, sports and bicycles and the dance craze of the 1920s opened up less cramped meeting opportunities. Young people were allowed increasingly to visit public dancing places and to organise private dance parties (only) for themselves.

In the Netherlands, the informalisation of courtship activities and engagements in good society also consisted of an erosion of this official pledge to marry and young people more easily breaking off their engagement. From the 1920s onward, this more easy-going attitude is documented from increasing complaints [by authors of Dutch manners books] about young people breaking off their engagements lightheartedly as well as from advice, based on this change, to scale down the engagement from a formal and public pledge to get married to a relatively small gathering, no longer the big ceremonious occasion that an engagement used to be.

1222 Educação \& Realidade, Porto Alegre, v. 42, n. 4, p. 1217-1234, Oct./Dec. 2017. 
In the social classes where young daughters usually would work as salesgirls, domestic servants, or in workshops, the codes of good society hardly functioned as a model, and parents traditionally allowed their offspring to attend meeting (and mating) occasions like fairgrounds or promenades for strolling. Couples would form, and many a marriage was arranged after a young woman got pregnant (Hessen, 1964). In their marriages, most husbands and wives followed traditional patterns of married life: strongly embedded in larger we-groups of families and characterised by a division of tasks and worlds between husbands and wives that in effect largely excluded confidentiality and relational intimacy (Straver et al., 1994). These traditions ruled in most villages and working-class neighbourhoods.

\section{New Practices and New Concepts}

The trend in the direction of young people escaping from under their parental wings and experimenting with erotic relations under their own steam can be presented by focusing on new words and practices.

An important new practice is indicated by the rise in the 1920s of the word verkering; it was derived from the verb verkeren, which means to be or move in [this or that] company. In the 1880s, the word acquired a romantic connotation, particularly when it was transformed into the noun verkering. As such, some people of the middle-classes understood it as a romantic relation preceding a formal engagement, while others saw it as a try-out relation that could develop into vaste verkering, a more fixed (=vast) commitment, similar to what became known as going steady in English. In Dutch good society, however, people looked down on verkering, both the word and the practice. In their view it was a disgustingly bad habit among the middle and lower classes, and they continued to perceive an engagement as the only proper arrangement that builds up to marriage. Thus, they tried to ban the practice by banning the word, and would always call their try-out relation an engagement, even when the couple had never been through a formal engagement ceremony (more details in Wouters, 2004; 2014). A demonstration of the long lasting power of this good society habitus is presented by a psychologist and journalist in her review of my 2012 book:

[...] Throughout the twentieth century there was no [Dutch] word for a romantic relationship with sexual implications. A couple could be married or engaged, but there was no name for the preceding phase, at least not in manners books giving advice on these thorny problems. The word verkering was used only in the vernacular and just did not apply to people in higher or bourgeois circles. Verkering or vaste verkering was something the kitchen maid had with her soldier. [...] For me, the term is saturated with insufferably petty and chiefly vulgar associations (Ritsema, 2012, n. p.).

Educação \& Realidade, Porto Alegre, v. 42, n. 4, p. 1217-1234, Oct./Dec. 2017.1223 
On Sexualisation and Eroticisation

Another new practice and neologism of the 1920s is scharrelen (literally: searching or groping movements, like chicken scratching, rummaging), a word used to indicate a relation with a girl for flirting, for fooling about and an affair that was not to become a serious love relationship. Girls who indulged in the practice could be called a scharrel and were in danger of being seen as a town bike. A similar negative word was the amatrice (female amateur). From the 1920s to the 1950s, it expressed the moral concern of Dutch upper and middle classes about the morality of girls in the younger generation. The amatrice was defined as "[...] the girl who gives herself to a friend in a loose-fixed relationship for which she is rewarded by being taken out often - to be distinguished from the professional prostitute" (Saal, 1950, p. 62). These girls had sex, which should not happen and if it did, it should be kept secret or denied, for even the suspicion of indulging in having sex could damage their reputation and respectability and, therefore, their future chances for a good marriage. But when denial became impossible, for example because more and more girls came to visit physicians and clinics with venereal diseases, the word amatrice was invented:

The appearance on the scene of the amatrice as a dramatis personae... is connected to the appearance of a premarital female sexuality that could no longer as a matter of course be localised only within the lower classes nor be lumped automatically under the heading of prostitution (Mooij, 1993, p. 136).

This figure of the amatrice evaporated completely in the Sexual Revolution. With the moral stigma removed, the amatrice became a girl with a steady relationship, a normal girl who had verkering or vaste verkering. She was, in fact, going steady.

In the second half of the 1930s, parental control over the younger generation had softened to the point that wise parents would not think of asking a young man for his intentions when he paid a little extra attention to their daughter, "[...] not even if he were to take her out frequently" (quoted in Wouters, 2004, p. 72-73). Parents were advised to give freer rein to their adolescent children by gedogen, conditionally allowing of such a practice, usually combined with a policy of cautious determent. In this way they tried to hang on by discreet yet distinct attempts at staying in the scene with their children, thus maintaining both an intimate bond and a guiding eye. It seems obvious, however, that particularly from the 1920s onward, the try-out relations of young people, whether called an engagement or a verkering, were becoming increasingly sexual (details in Wouters, 2004; 2014).

\section{Process Continuities in Class Differences before and after the 1960s}

The sexualisation of try-out relations was observed in all social classes, it was part of a general trend, and yet, some differences between the social classes continued from before the 1960s into later decades; 
these differences did change in many respects but from a relational perspective, some of them continued and, therefore, they can be indicated as process continuities. A significant one is that, in comparison to girls and boys from middle and upper classes, their young counterparts from lower social classes generally got married at an earlier age. It is one of the traces of a traditional pattern that persisted among them. Another one is that social control over the young is less directed at learning them to steer themselves and more at demanding their obedience in combination with a rather partial supervision and a tacit policy of don't ask, don't tell. This policy is directly related to an understanding of the budding sexuality of boys and girls as a natural force that finds its way and that among them, acquiring sexual experience is highly regarded and status enhancing. Belonging to the same traditional pattern are the findings that these youngsters usually start tentative sexual relations at an earlier age than their contemporaries of higher social classes and that they proceed more quickly from first contact to full intercourse. These and other examples of greater sexual directness are reported in sociological and sexology studies and they are discussed in Wouters (2012).

Young people from higher social classes report more reserve in developing relational and sexual trajectories. Among them, masturbation is reported more often. On average they are later with starting an intimate (try-out) relationship and also take more time than their counterparts from lower social classes before they get to experience full sex. They are more reticent in getting there because they want to develop a mutual consent that includes being ready for the experience. This reticence is most probably related to an upbringing that focuses less on obedience to parents and other authorities and more on learning to decide for oneself. At the same time, increasing parental trust in the self-steering abilities of children has reduced the old fear among parents that their offspring would lack self-control and let themselves go sexually when social control was absent. It seems obvious that these differences between the classes concur with differences in the development of self-steering.

\section{Connecting Sexual and Relational Intimacy: trial and error since the 1960s}

Despite many fluctuations, accelerations and counter-currents at many levels of complexity, on the whole, trial and error processes went in the direction of a sexualization of love (involving mainly women) and an eroticization or sensualisation of sex (mainly men). Particularly in the collective quest how to connect sexual with relational intimacy, prominent moments can be distinguished. Five such moments will now follow; four are described in greater detail and are more elaborately backed up with data in Wouters (2004), the fifth one in Wouters (2010).

The first moment is the Sexual Revolution. At that time, young people were breaking the taboos of previous generations to such a degree that there was an acceleration in the emancipation of sexual emotions

Educação \& Realidade, Porto Alegre, v. 42, n. 4, p. 1217-1234, Oct./Dec. 2017.1225 
On Sexualisation and Eroticisation

and impulses - allowing them into consciousness and public debate. Women rejected their traditional submissiveness towards male superiority to the extent that it became socially accepted for them to participate in public discussions on sexuality and a more gratifying lustbalance. They subjugated their traditional shame and shame-triggered counter-impulses involving lustful and sexual feelings; they stopped answering questions regarding sexuality more traditionally conservative than men; and in the early 1970s, they silenced men who were still complaining about their wife getting an orgasm too slow, by venting complaints about husbands having their orgasm too fast. In a short period of time, the relatively autonomous strength of carnal desire came to be acknowledged and respected. For both genders, sex for the sake of sex changed from a degrading spectre into a tolerable and thus acceptable alternative, allowing more women and men to experiment with sex cheerfully and outside the boundaries of love. At the time, the spirit of liberation from the straitjacket of older generations prevailed, and did not allow much attention to be given to the demands of liberation.

From the late 1960s onward, as living together without being married became socially accepted and marriage receded as the only acceptable aim of starting a try-out relation, the number of people getting formally engaged strongly diminished and the word verkeringlost much of its function and tended to become obsolete. This trend accelerated in the next decades with the spread of to have a relation (with someone) to indicate a sexual and romantic relation (for the sake of such a relation). In one respect, the word relation went through the same development as the word verkeren: it acquired a sexual and romantic connotation - in the 1950s (Instituut Voor de Nederlandse Taal, 2015) - and over the next decades, this connotation gained strength.

The period between 1968 and 1974 was one of rapid major transitions. An indication is that the reported sexual experience of young people in the Netherlands doubled while their attitudes in matters of sexuality became twice to three times more permissive. More important is that in these years, a trend in teenage sexuality appeared that would continue during subsequent decades until today: the principal conditions for parental consent to their teenagers having sex and also for a romantic and sexual sleepover had become: feeling strongly for each other and mutual consent about being ready for it, that is, ready for sex as an exploration of physical, personal and relational feelings (Wouters, 2012).

A second remarkable moment in the collective trial and error process is in the second half of the 1970s, when women brought about a shift in emphasis from sexual liberation (from parental sexual codes) to sexual oppression (by men): now, opposition turned against the codes and morals of the dominant sex, against sexual violence, and pornography came to be seen as (triggering) sexual violence. Around 1980, massive anti-pornography demonstrations were held by women, thus clinging to their romantic relational ideal of love. At the same time, however, there were discussions about women who enjoyed only one- 
night stands thus excluding sexual intimacy from other forms of intimacy; their longing for relational intimacy had come to be experienced as an obstacle to sexual pleasure. They avoided any emotional commitment in having sex. According to tradition, a woman should have sexual desires and fantasies only within a romantic relationship that was meant to last a lifetime. In a lust-balance that is tipped the other way, a woman's sexuality could be aroused only outside such a relationship, in almost anonymous, instant sex. This compartmentalization of sexuality or "sexual separatism" (Lasch, 1979, p. 338) clearly showed women to be moving in between the extremes of love without the ballast or duty of sex and sex without the ballast of love.

As an undercurrent, this lust balance formed the negative of that propagated by the anti-pornography movement. To a large extent that movement was an emancipation cramp, expressing problems connected with the emancipation of sexuality, for the attack on male pornography concealed as well as expressed a fear of freedom (in Erich Fromm's famous phrase), a fear of experiencing and presenting oneself as a sexual subject. This fear was expressed in the anti-porn movement as well as in sexual separatism, and either way, the opposite sex was seen as the origin as well as the solution of all difficulties. No woman will have been able completely to withdraw from this development and its inherent ambivalence, if only because, before the sexual revolution the social code allowed women to express only one side of the lust-balance.

In some respects, men appeared to be in a similar transition. Sexology studies from the early 1970s indicate, for example, that many married men still reported a preference for keeping an emotional distance to their wife when having sex; this preference for sexual separatism probably was connected with a similar experience as the women who separated sexual intimacy from other forms of intimacy, namely that emotional intimacy disturbs their sexual appetite. By 1981, however, a sexology study showed that the number of men reporting to prefer an emotional distance when having sex with their wife had strongly declined. Apparently, they no longer wanted her mainly as a sexual object, but also as a sexual subject. In the same period, this shift can also be deduced from a decline in the percentage of men who expressed a strong aversion to oral sex (eating pussy). It had dropped from 50 percent in 1971 to 20 percent in 1981 (Vennix, 1989).

A third prominent moment in the collective trial and error process consisted of a lust revival. From the mid1980s to the early1990s, the emancipation cramp was overcome and a more relational outlook, and a (female) lust revival surfaced, together with public discussions on such topics as men as sexual objects, women's adultery, masturbation, and with the success of groups of male strippers like Chippendales and the launch of female pornography, the emancipation of female sexuality and the sexualisation of love accelerated again, both among a new generation of young women and among feminists, of whom a leading older one looked back at the anti-pornography movement as a kind of puritanism (Meulenbelt, 1988).

Educação \& Realidade, Porto Alegre, v. 42, n. 4, p. 1217-1234, Oct./Dec. 2017.1227 
On Sexualisation and Eroticisation

The change among men was again in the direction of experiencing women less as sexual objects, also as sexual subjects. In 1989, half of the men reported the practice of giving oral sex as a regular one (Vennix, 1989).

A comparison of teenagers of the 1980s generation (born in between 1968 and 1972) with what their parents of the 1950s generation (born between 1938 and 1945) reported on their youth (Ravesloot, 1997) shows huge changes: from strict hierarchical relations in which much was obliged, little allowed, sex a taboo, and many reporting memories of surreptitious attempts to escape this rigid regime... to giving their teenage children the possibility of growing into a sexual human being by allowing them to experiment with try-out relations until one of these would be intimate enough for the young couple to decide being ready for it.

The fourth moment in the process of sexualisation and eroticisation was from the late 1980s into the 2000s, when both longings of the lust-balance were becoming integrated on a higher level, allowing more sex and expecting more love, which implied that female emancipation was not only expressed in acknowledgement of the principle of mutual consent but that of mutual attraction as well. During these years there was a love and lust revival. As an ideal, sexology research of 1990 finds that, most young people think of love and sexual pleasure as two sides of the same coin, and this goes for both boys and girls. Sexologists also report young people in 1990 to begin with sexual relations at an earlier age while also postponing marriage and/or having children to a later age, and in this longer in-between period they report a trend of having more subsequent monogamous try-out relations, characterised as serial monogamy and short fidelity (Vliet, 1990; Vogels; Vliet, 1990).

The emancipation of female sexuality and its counterpart, the eroticisation and bonding of male sexuality, was channelled not only by literature (like feminist publications), by protest activities (like those against sexual violence and harassment) and by changes in the law such as making rape in marriage liable to penalty and welfare arrangements providing the material basis for many women to develop an equanimity of the welfare state (Stolk; Wouters, 1987), but men were also caught in a pincer movement, in between their longing for an enduring intimacy on the one hand becoming subjected earlier and more strongly to more or less rigorous limitations such as desertion and divorce or the threat of them, and, on the other hand, their longing for satisfying their own sexuality becoming increasingly dependent upon their talent for arousing and stimulating a woman's sexual desires.

A fifth striking moment in the collective trial and error process towards a further integration of love and lust was in the first decade of the twenty-first century with the international outbreak of an attack on sexualisation and pornification. At first sight, this attack may give a different impression than that of a continued integration of love and lust because both these concepts, pornification in particular, do carry strong negatively loaded moral connotations. On closer inspection, however, these 
protests predominantly symbolise a new emphasis on the love-side of the lust-balance, for in comparison to love, sex had become relatively easy. If the old anti-porn movement symbolised an attempt at more sex with love, the new one symbolised an attempt at more love with sex. The long-term process of sexualisation and eroticisation clearly continued as before in the direction of emancipation of sexuality and certainly not in the direction of the preceding long-term process of desexualisation, in which taboos on sexuality had gained strength.

In the Netherlands, the latest manifestation of the quest for combining more relational intimacy with sexual intimacy is the slow sex movement. The people involved in this slow sex movement attacked the sex of pornography, seen mainly as mechanical, vulgar, and loveless, but their attack was not so much directed against pornography, it was more an outcry for a higher quality of sex - sex as haute couture - and that quality was sought in the further integration of relational intimacy with sexual intimacy. The most successful outcry was a book called $M c$ Sex: Die Pornofizierung unserer Gesellschaft, its German title (Hilkens, 2010). Its author lived a life of chasing sexual gratification until she experienced it as empty; her attack on pornification is predominantly in favour of eroticising sex and, therefore, in favour of a lust-balance that further integrates relational and sexual intimacy.

Moreover, protests against pornification and sexualisation will keep lust-balance questions topical, thus raising the erotic and sexual presence of mind and the sensitivity to erotic and sexual aspects of relations. They are, therefore, instrumental in propelling further sexualisation and eroticisation in the sense of further emancipation and integration of sexuality. Accordingly, sexualisation and eroticisation processes have neither stalled nor changed direction, quite the contrary: it seems much more likely that they are accelerating (Wouters, 2010).

However, young people's attempt at integrating sexual longings into a personally gratifying and socially acceptable lust-balance, is still very much in full swing of development. Continued tensions and shifts in the social definition of what constitutes an ideal lust-balance also allow the conclusion that the Sexual Revolution has not ended. Individuals as well as societies still struggle with its aftermath, as is recently demonstrated from the confusion, moral fervour and moral indignation of attacks on sexualisation and on paedophiles.

In 2015, HBSC-research (Health Behaviour in School-aged Children), collecting data in 44 western countries, reported Dutch children to lead the list of having good communications with their parents and feel they can talk to their parents about their problems (Kuntsche et al., 2015). Probably, many parents and adolescents would also want to talk more openly about sex, but they don't know how, as they are again and again overcome by some kind of confusion. Discussing problems of the lust-balance is still quite difficult as these are surrounded by relatively high levels of shame and embarrassment, particularly if discussing personal sexual problems, fears and desires. Even with their peers most teenagers find it difficult to talk about their own sexual experi-

Educação \& Realidade, Porto Alegre, v. 42, n. 4, p. 1217-1234, Oct./Dec. 2017.1229 
On Sexualisation and Eroticisation

ences and longings, but between them and their parents, a specific obstacle had developed (except in cases of incest), because it was in this relationship that intimate touching and other physical contact had not been recognised (not mirrored) and was even banned from relation and conversation. At the same time, as children were growing up, emotional intimacy in this relation has risen to a level at which any other relation would (have) become sexual. This creates a tension that may explain the confusion about paedophiles.

\section{Where are We Now? Obstacles, Pulls and Pushes}

As both mutual and parental consent became more dependent upon the strength of feelings for each other and the depth of the relation rather than upon age or something else, teenagers could feel relatively free to grow into being ready for having sex together. In 2005, having strong feelings for each other sufficed for $80 \%$ (was $75 \%$ in 1995) of the Dutch school population (aged 12 years and older) as a precondition for having sex (Graaf et al., 2005). As these numbers were rising, the traditional observation that girls love boys more than sex and boys love sex more than girls was eroding. Particularly after having acquired sexual experience, “[...] young people think of love and sexual pleasure as two sides of the same coin, and this goes for both boys and girls" (Vliet, 1990, p. 70-71).

In this process, the word love took on old-fashioned romantic connotations, and in reaction, many shunned it or overused it, thus thinning down old pretensions that now demand more caution. Particularly in the early phases of experimental try-out relations the word love became too heavy to use, but in the same gasp, virtually all old words for a love-relation came to be stigmatised for smelling of old-fashioned inequality, of horse and carriage and children in marriage. Expressions such as going steady, verkering, being engaged, and vaste verkering, a steady relationship are dropped or postponed as long as possible. They tend to reappear, however, in the language of parents and teachers at nursery and primary schools when talking about the intimate peer relationships of young children, from the ages of three and four upward. One may hear, for example, that Olivia is Sam's fiancé, that Oskar and Julia have verkering and that these couples are in love - an example of overusing the word love. The word puppy love, however, is carefully avoided. It has disappeared like most ridiculing expressions.

In some of their try-out relations, teenagers and adolescents even avoid the word relation (the ship of relationship had already been dropped earlier [?]) because it would suggest that one's partner choice is made, lock, stock and barrel, and independence has been renounced. They use euphemisms such as having something [a thingy] with someone, they see someone or refer to my friend with many variations in emphasis on the first or the second word, but without further specification. There is great ingenuity in avoiding traditional connotations. Young Dutch people (in their late teens and twenties) have introduced the words pre- 
la and rela (Julen, 2015), the latter consists of the first letters of the word relation, thus indicating only half the commitment and obligations of a full relation ${ }^{2}-$ which is more publicly known and acknowledged by at least parents and friends. A prela refers to a phase before a rela. The prela may or may not be monogamous, but the rela and the relation are (supposed to be). Before the prela, there may be a phase of dingesen, a neologism (thinging), or of scharrelen, an old word that today has lost its negative connotation. This fading provides a nice example of the connections between the emancipation of women, young people, and their sexuality. Today, scharrelen means having an affair with someone just for the pleasure of it (for the sake of the affair), that is, without serious intentions or commitments or claims about the future. And the practice of scharrelen is placed early in serial try-out relations as an early phase in learning about love and lust. In a personal communication, a female journalist in her early twenties wrote me:

Girls often use the word when talking as women amongst each other. 'We scharrel a bit'. That even sounds tough: 'Oh indeed, a man, but ah, you know, just for the fun of it'. Many people of my generation think it is quite normal to first have a period of 'scharrelen' before getting a bit more serious; they don't want to get into a prela or rela straight away (Sadelhoff, 2015, p. 20).

Another recent expression, used in the Netherlands, is flow; young people speak about my flow and of being in a flow with someone. This expression is probably taken from the concept flow as developed by the Hungarian-American psychologist Mihaly Csikszentmihalyi, basically meaning complete absorption in what one does, and taken to town by using it for a try-out relation involving sex.

These concepts and expressions, dingesen, scharrelen, having a prela or a rela and being in a flow are all vague, and they breathe embarrassment for fear of getting into a more serious full relation too soon. Some interpret this vagueness as stemming from young people's reluctance to commitment, enjoying their freedom and a varied sexual menu; most of them thought to be men, of course. Indeed, these people do exist, they have different demands and expectations, but they characteristically fail to feel and show the embarrassment that is characteristic of the whole quest for concepts and expressions that can possibly convey the various different phases in the development of love and sex, of lust-balance relations and experiences. The most important condition for entering into a commitment is in the feeling for someone, and it seems that as long as one did not get at the root of that feeling, the commitment is postponed. Instead, there is a prela, a rela or a flow or something.

The quest for new concepts can be taken as another signal that to feel strongly for each other, to love and to make love are increasingly perceived as learning processes with various stages or phases. From this perspective, it is obvious that all phases of this trial and error process of learning to develop a gratifying lust-balance are taken increasingly

Educação \& Realidade, Porto Alegre, v. 42, n. 4, p. 1217-1234, Oct./Dec. 2017.1231 
serious. For many young people today, the duration of this quest for a gratifying lust-balance, with its various phases and variety of try-out relations, takes longer and also more subsequent partners than they and/ or their parents might wish, but both are much more likely to have originated from a rise rather than a decline in their longings and demands for intimacy and confidentiality.

The main drivers of the emancipation of sexuality are not only related to rising levels of equality and intimacy between women and men, but also to rising expectations about what constitutes a gratifying lustbalance. Emancipation processes and decreasing inequality in gender relations implied that both women and men developed higher expectations of their love life, and as parents developed higher expectations of their family life, and that they accordingly make higher demands on each other. There is a paradox in the connection between these rising expectations and demands on the one hand, and fidelity relations lasting shorter and shorter on the other: increasing numbers of young people live an increasing number of subsequent relatively short try-out relations, and also adults tend increasingly to live in relations of serial monogamy. Rising expectations of love and rising demands on each other did not prevent divorce rates to decline, quite the contrary, but this rise, too, is much more likely to have originated from a rise rather than a decline in demands for intimacy and confidentiality. These rising demands and expectations largely explain the new emphasis on the love-side of the lust-balance, in this century, and also why love has become more difficult, lasting love in particular.

Yet, once established levels of equality and intimacy are likely to be maintained and transmitted to the next generation. Children and teenagers who grow up on a certain level will expect to develop a similar or, if possible, even a higher level of intimacy and equality in relations of love and friendship with people of their own generation. It becomes their relational ideal. From a very early age onwards these ideals and expectations become deeply integrated in the habitus level of their personality as a relational code and ideal, providing significant sources of meaning and value in life. Therefore, young people will long for similar degrees of intimacy and openness in their own intimate relations as they have experienced in their youth. These longings and the whole quest for further integration of sexual and relational intimacy is most likely to stimulate continued sexualisation and eroticisation.

Received on April 25, 2016 Approved May 4, 2017

\section{Notes}

1 This article is based upon previous research published in English (2004, 2007 and 2010) and in Dutch (2012). The latter is a monograph largely based upon Dutch sexology studies, which implies an emphasis on processes in the Netherlands, but I think and hope the sequence and details are useful for international 
comparisons and the general line of these developments is recognisable all over the wealthy West.

2 Searching in Dutch etymological dictionaries for the word relation suggests that when it appeared in the domain of intimacy (first half $20^{\text {th }}$ Century), its main connotation was sexual, as in an extra-marital relation, that it acquired erotic/romantic connotations only later, and that, subsequently, the latter connotation gained strength, probably hand in hand with the emancipation of sexuality.

\section{References}

ELIAS, Norbert. On Human Beings and Their Emotions: a process-sociological essay. In: ELIAS, Nobert. Essays III: on sociology and the humanities. Dublin: UCD Press, 2009a. P. 141-158.

ELIAS, Norbert. Social Anxieties. In: ELIAS, Norbert. Essays III: on sociology and the humanities. Dublin: UCD Press, 2009b. P. 138-140.

ELIAS, Norbert. On the Process of Civilisation: sociogenetic and psychogenetic investigations. Dublin: UCD Press, 2012.

FONAGY, Peter. A Genuinely Developmental Theory of Sexual Enjoyment and Its Implications for Psychoanalytic Technique. Journal of the American Psychoanalytic Association, Thousand Oaks, v. 56, n. 1, p. 11-3656, 2008. Available on: <http://apa.sagepub.com/cgi/content/abstract/56/1/11>. Access on: 27 Sept. 2015.

GOUDSBLOM, Johan. Fire and Civilization. Harmondsworth: The Penguin Press, 1992.

HESSEN, J.S. Van. Samen Jong Zijn: een jeugdsociologische verkenning in gesprek met vorigen. Assen: Van Gorcum, 1964.

HILKENS, Myrthe. McSex: die pornofizierung unserer gesellschaft. Berlin: Orlanda Frauenverlag, 2010.

INSTITUUT VOOR DE NEDERLANDSE TAAL. Woordenboek der Nederlandsche Taal. Amsterdam: WNT, 2015. Available on: <http://www.inl.nl/onderzoek-a-onderwijs/lexicologie-a-lexicografie/wnt>. Access on: 16 Oct. 2015.

JULEN, Jeannine. Een Rela? Nee Joh, We Zijn Aan Het Dingesen. TrouwTijd, Amsterdam, v. 1, n. 1, p. 7-10, 2015.

KUNTSCHE, Emmanuel; ULRIKE, Ravens-Sieberer (Ed.). Monitoring Adolescent Health Behaviours and Social Determinants Cross-Nationally over more than a Decade: introducing the health behaviour in school-aged children (HBSC) study supplement on trends. European Journal of Public Health, Oxford, v. 25, n. 2, p. 1-3, 2015.

LASCH, Christopher. The Culture of Narcissism. New York: Warner Books, 1979. MEULENBELT, Anja. Homoseks en Feminisme. Opzij Magazine, Amsterdam, v. 9, n. 43, 1988.

MOOIJ, Annet. Geslachtsziekten en Besmettingsangst: een historisch-sociologische studie 1850-1990. Amsterdam: Boom, 1993.

RAVESLOOT, Janita. Seksualiteit in de Jeugdfase Vroeger en nu: ouders en jongeren aan het woord. Amsterdam: Het Spinhuis, 1997.

RITSEMA, Beatrijs. Op Zoek Naar Een Ideale Lustbalans Voor Je Kind. Amsterdam: NRC Handelsblad Boeken, 2012.

Educação \& Realidade, Porto Alegre, v. 42, n. 4, p. 1217-1234, Oct./Dec. 2017.1233 
On Sexualisation and Eroticisation

RÖLING, Hugo. Zichzelf te Zien Leven: herinneringen aan Nederlands en vlaams gezinsleven 1770-1970. Amsterdam: Amsterdam University Press, 2006. SAAL, C.D. Hoe leeft en denkt onze jeugd: resultaten van een in 1946-1947 gehouden enquête. Gravenhage: Boekencentrum, 1950.

SADELHOFF, Lisanne Van. Van Prela naar Rela. AD Magazine, Amsterdam, n 7, p. 20-23, 2015.

STOLK, Bram van; WOUTERS, Cas. Frauen im Zwiespalt: beziehungsprobleme im Wohlfahrtsstaat - eine modellstudie. Frankfurt am Main: Suhrkamp, 1987.

STRAVER, C.J. De Huwelijkse Logica: huwelijksmodel en inrichting van het samenleven bij arbeiders en anderen. Leiden: DSWO Press, 1994.

VENNIX, Paul. Seks en Sekse: verschillen in betekenisgeving tussen vrouwen en mannen. Delft: Eburon, 1989.

VLIET, Ron van der. De Opkomst Van Het Seksuele Moratorium. Amsterdams Sociologisch Tijdschriftm, Amsterdam, v. 17, n. 2, p. 51-68, 1990.

VOGELS Ton; VLIET, Ron van der. Jeugd en Seks. Den Haag: SDU, 1990.

WOUTERS, Cas. Sex and Manners: female emancipation in the west, 1890-2000. London: Sage, 2004.

WOUTERS, Cas. Informalization: manners and emotions since 1890. London: Sage, 2007.

WOUTERS, Cas. Have Sexualisation Processes Changed Direction? Sexualities, Thousand Oaks, v. 13, n. 6, p. 723-741, Dec. 2010.

WOUTERS, Cas. De Jeugd van Tegenwoordig. emancipatie van liefde en lust sinds 1880. Amsterdam: Athenaeum-Polak \& Van Gennep, 2012.

WOUTERS, Cas. No Sex under my Roof: teenage sexuality and status competition in the USA and the Netherlands since the 1880s'. Human Figurations, Michigan, v. 3, n. 2, Jun. 2014. Available on: <http://hdl.handle.net/2027/ spo.11217607.0003.205>. Access on: 8 Oct. 2015.

WOUTERS, Cas. Informalisation and Evolution: from innate to collectively learned steering codes - four phases'. In: WALDHOFF, Hans-Peter; MORGENROTH, Christine; MORÉ, Angela; KOPEL, Michael (Hg.). Wo Denken wir hin? lebensthemen, zivilisationsprozesse, demokratische verantwortung. Gießen: Psychosozial-Verlag, 2015. P. 261-296.

Cas Wouters studied Sociology at the University of Amsterdam. Researcher at Utrecht University, and the Amsterdam School for Social Science Research (ASSR). Research topics such as social and psychic processes throughout the twentieth century, especially 'processes of informalization', behaviors, power relations and control of emotions, from the theories of Norbert Elias. His research has been published in several countries in Europe and the USA. He acted and produced with Norbert Elias.

E-mail: c.a.p.m.wouters@uu.nl 